Krzysztof Kamiński*

\title{
Nietraumatyczne a smutne okoliczności śmierci w kontekście intelektualnej biografii Stefana Swieżawskiego
}

\begin{abstract}
Streszczenie: Aby pogrzeb nie był postrzegany jako wielka trauma - krańcowy przejaw nieszczęścia (w przeciwieństwie do wydarzenia jedynie smutnego) - musi być spełnionych kilka podstawowych warunków. Po zaprezentowaniu tych warunków w artykule zastanowimy się, czy ich spełnienie jest jedynie wynikiem niedefiniowalnego i przypadkowego w swojej genezie szczęścia życiowego, czy trzeba szczęściu pomagać, by się ziściło? Odpowiedzi oczywiście będziemy poszukiwać w intelektualnej biografii Swieżawskiego.
\end{abstract}

Słowa kluczowe: biografia intelektualna, Stefan Swieżawski, życie-śmierć.

\section{Not traumatic and only sad circumstances of death in the context of an intellectual biography of Stephen Swieżawski}

Summary: In order for the funeral not seen as a great trauma - a manifestation of extreme unhappiness (as opposed to just a sad event) - several basic conditions must be fulfilled. After introducing these terms in the article, we consider whether meeting them is only the result of indefinable and accidental, in its genesis, happiness in life, if the happiness must be helped to come true? Of course we will look for the answers in the intellectual biography of Swieżawski.

Keywords: intellectual biography, Stefan Swieżawski, life-death.

Pogrzeb osoby bliskiej zawsze będzie dla pozostających wydarzeniem przynajmniej smutnym. Bolesna jest świadomość ziemskiej rozłąki - jeszcze trudniej bywa, gdy żyje się z przekonaniem, że jest to rozłąka ostateczna. Jest wiele też okoliczności, które mogą dodatkowo potęgować negatywne doznania. Żeby po-

*Wyższa Szkoła Pedagogiczna w Łodzi; krzysztof.kaminski@wsp.lodz.pl, www.kaminski-ebik.eu 
grzeb nie był jednak postrzegany jako trauma (krańcowy przejaw nieszczęścia), musi być spełnionych kilka podstawowych warunków:

- żegnany powinien dożyć sędziwych lat (najlepiej we względnym zdrowiu),

- bilans życiowy powinien być dodatni, czego osoba odchodząca powinna być świadoma,

- jak wiele sytuacji obrazuje, pewnym „ułatwieniem” może być życie i umieranie w klimacie teologicznej wiary - mając na uwadze sprawy eschatologiczne,

- dzieło życia powinno znaleźć uznanie (być kontynuowane, powielane, wspominane z uznaniem) wśród tych, co zostają: rodzina, uczniowie, epigoni - krótko mówiąc - chodzi o dobrą pamięć. Zła pamięć skłania w tych okolicznościach do milczenia...

Kontynuując (sic!): chcę przywołać postać Stefana Swieżawskiego ${ }^{1}$ i kilka biograficznych faktów - głównie z biografii intelektualnej. Sygnalizowany wątek osobisty będzie jedynie drobnym kontekstem, ale ściśle komponującym się z motywem przewodnim prezentowanych omówień ${ }^{2}$.

Powszechnie znane jest heideggerowskie ujęcie człowieka jako bytu $k u$ śmierci. Uświadomienie sobie własnej śmiertelności (100\% ludzi umiera) może paraliżować życie, może skłaniać do ambiwalentnych wniosków, ale może też mobilizować do dobrego życia (cokolwiek dobre życie miałoby znaczyć). We wspomnieniu po śmierci przywołanego Profesora, wybitnego uczonego, ale także człowieka o wielkim autorytecie moralnym, pisałem:

Swieżawski o śmierci mówił często i zawsze z nadzieją. Głęboko wierzył, że życie się przemienia, ale nie znika. Fakt śmierci - podkreślał w swoim Alfabecie duchowym - wymaga od nas przemiany duchowej o wiele większej niż akceptacja rewolucji kopernikańskiej w astronomii. Chrześcijanin jest powołany przez swoją wiarę do trwania w stanie największej rewolucji. To, co wydaje się śmiercią, naprawdę jest dopiero pełnym życiem. Jasno zdefiniowana nadzieja eschatologiczna Swieżawskiego pod żadnym pozorem nie bagatelizowała jednak doczesności.

${ }^{1}$ Stefan Swieżawski (1907-2004) - wybitny historyk filozofii średniowiecznej i największy w Polsce znawca pism św. Tomasza z Akwinu. Jeden ze świeckich audytorów Soboru Watykańskiego II, bliski przyjaciel Jana Pawła II. Studia ukończył we Lwowie. Współpracował m.in. z Katolickim Uniwersytetem Lubelskim i Polską Akademią Nauk. Był jednym z duchowych ojców środowiska „Tygodnika Powszechnego" i „Znaku”. Autor ośmiotomowej monografii Dzieje filozofii europejskiej XV wieku jak również obszernej (trzytomowej) autobiografii: Wielki przełom (1907-1945), Lublin 1989; W nowej rzeczywistości (1945-1965), Lublin 1991; Owoce życia (1966-1988), Lublin 1993. Bogata autobiografia jak również obszerny dorobek naukowy mogą stać się przedmiotem wielorakich badań, oczywiście także w kontekście badań biograficznych.

${ }^{2}$ Wiele lat spędziłem nad studiowaniem dorobku naukowego Swieżawskiego, czego czytelnym znakiem pozostaje m.in. publikacja książkowa z 2007 r. Humanizm chrześcijański Stefana Swieżawskiego (www.leksem.pl), Łask, skąd pochodzą obszerne, poprawione fragmenty niniejszego przedłożenia. Miałem również zaszczyt spotkać się osobiście z profesorem Swieżawskim w jego mieszkaniu, w Warszawie, w 2001 r. Owocem spotkania jest wywiad ze Swieżawskim opublikowany w „Gościu Niedzielnym" z 27 stycznia 2002 r. (nr 4), s. 16, jak również w ww. książce, s. 309-315. W dniu 22 maja 2004 r. uczestniczyłem w pogrzebie Swieżawskiego w podwarszawskich Laskach. 
Przeciwnie. Swieżawski był gorliwym jej apologetą - z całą stanowczością ukazywał jej wielkość i piękno przez wielkość i piękno filozofii: jestem przekonany - pisał - że każde dzieło ludzkie w miarę jego wartości obiektywnej będzie utrwalone i nie zostanie unicestwione na wieczność (Kamiński, 2004, s. 427-429).

Od czasu podjęcia decyzji o wyborze studiów Swieżawski pozostawał wierny filozofii - pasji, w której już wcześniej się rozmiłował, i religii chrześcijańskiej, którą wyniósł z domu rodzinnego. Nigdy nie zaniechał formacji filozoficznej i nigdy nie sprzeniewierzył się inspiracjom płynącym z kart Ewangelii. Już od czasów studenckich, kiedy to działał w lwowskim Stowarzyszeniu Katolickiej Młodzieży Akademickiej „Odrodzenie”, zajmował się, jak to nazywa, meblowaniem głów w sekcji filozoficzno-religijnej, nad którą wówczas sprawował pieczę (Swieżawski, 1989, s. 149). Całe jego późniejsze, dojrzałe życie intelektualne podporządkowane było dążeniu do mądrości i prawdy. Historyczne spektrum filozofii i autentyczna Ewangelia znaczyły jego twórczą działalność aż po Alfabet duchowy, książkę, nad którą pracował tuż przed swoją śmiercią w maju 2004 r. Wojciech Bonowicz, wspominając w jej wstępie, że Swieżawski był wybitnym historykiem filozofii i człowiekiem wielkiej wiary, swoją wypowiedź zakończył: „Dla wielu z nas - był prorokiem” (Bonowicz, 2004, s. 5).

\section{Rola historiografii filozoficznej}

Perspektywa historyczna filozofii, stanowiąc rzeczywistość jednocześnie bogatą i tajemniczą, stwarza nieograniczoną wręcz możliwość jej ujmowania. Świadomy tego Swieżawski z uznaniem odnosi się do głoszonej przez Władysława Tatarkiewicza ${ }^{3}$ zasady interwencjonizmu w uprawianiu historii filozofii, którą odnosi zarówno do mnogości aspektów przedstawiania przedmiotu historii filozofii, jak i względem różnorodności koncepcji filozoficznej historiografii (Swieżawski, 1978a, s. 260). Tatarkiewicz wyjaśniał:

Historycy są jak studenci w akademii, którzy malują z modela: każdy siedząc w innym miejscu, widzi go inaczej, niemniej każdy może go odmalować wiernie. A różne punkty widzenia uzupełniają się i korygują wzajem. Z interwencjonizmu nie wynika, by historia musiała być subiektywna: wynika natomiast, że musi, jak zresztą każda nauka, być wysiłkiem zbiorowym, że tylko stopniowo zbliżać się może do celu, że interwencja interwencję uzupełnia (Jaworski, 1975, s. 49).

3 Swieżawski Władysława Tatarkiewicza określa mianem wielkiego humanisty. Czyni to w kontekście namysłu nad zagadnieniem kultury. W. Tatarkiewicz, jak podkreśla, stojąc na straży wartości istotnych dla kultury, wskazywał na filozofię i nauki humanistyczne, jako na dziedziny decydujące o losach jej rozwoju (por. Swieżawski, 1978a, s. 260). 
Swieżawski, mimo że jest zwolennikiem łączenia w historiografii filozoficznej historii filozofów z historią problemów filozoficznych, to z punktu widzenia potrzeb filozofii, jako głębszą i o wiele wartościowszą, wskazuje historię ujmowaną od strony problemów filozoficznych. Zaznacza, że

właściwy nerw dziejów filozoficznych przebiega poprzez spięcie, zarówno między konkretnym człowiekiem, a wymykającym się spod zasięgu uwarunkowań czasowo-przestrzennych pytaniem filozoficznym, jak i między tym, co w filozofii nowe, co zjawia się po raz pierwszy, i tym, co nieprzemijające, wieczne, klasyczne (Swieżawski, 1978a, s. 259).

Mieczysław Albert Krąpiec podkreślał wręcz, że Swieżawski historię filozofii postrzegał nie tylko jako historię pism, ale jako będącą w ciągłym rozwoju żywą myśl. Wskazywał, że w tym rozumieniu historii był kontynuatorem swego mistrza - Étienne'a Gilsona. To Gilson, którego, podobnie jak Swieżawski, nazywa najwybitniejszym współczesnym historykiem filozofii, dzięki doskonałej znajomości dziejów myśli filozoficznej mógł dostrzec prawdziwościowy, klasyczny ciąg filozoficznej interpretacji rzeczywistości świata i ludzi (Krąpiec, 1997, s. 63-64).

Uczeń Swieżawskiego, Karol Tarnowski, zwraca z kolei uwagę, że entuzjazm Profesora wynikający z faktu obcowania z historią filozofii obwarowany jest dwoma przekonaniami. Po pierwsze, że każdy ludzki rzetelny wysiłek jest wartościowy. Po wtóre, wskazuje na wiarę w wartość ciągłości kultury. Dostrzega tu pewien kierunek i sens. Podkreśla, że zarówno zaniedbania i błędy, jak i genialne intuicje owocują po wiekach niemożliwymi do wymazania konsekwencjami (Tarnowski, 1997, s. 97).

Swieżawski, mówiąc o formacji umysłowej, wskazuje na jej podstawowe odmiany: filozoficzno-humanistyczną i religijną, wobec których ogromną rolę - nie tylko czysto naukową, ale także wychowawczą, w szerokim tego słowa znaczeniu - ma do spełnienia właśnie historia filozofii (Swieżawski, 1978b, s. 62).

Swieżawski wielokrotnie podkreślał, że każdy, kto pozostaje w kręgu filozofii powinien znać jej całą historię. Niestosownością, obniżającą poziom naukowych badań, jest ograniczanie się tylko do wybranych epok. „Wszystko jest ważne, ponieważ w metafizyce lub antropologii filozoficznej prawdy, do których się dochodzi, są pozaczasowe. To, co mówił Platon lub Leibniz, to, co prawdziwe jest w nauczaniu nam współczesnych z zakresu tych dziedzin - pozostanie na zawsze prawdziwe" (Swieżawski, 1997, s. 16). W ogóle zaś nie do pomyślenia jest dla Swieżawskiego ahistoryczne uprawianie filozofii. Jest przekonany, że historia filozofii ma ważne zadanie do spełnienia wobec samej filozofii. Jest ona bowiem, jak podkreślał, z ,punktu widzenia realizmu, właściwym polem doświadczalnym i najlepszym warsztatem dla refleksji filozoficznej" (Swieżawski, 1978a, s. 263264). Stąd za słuszne uzna Swieżawski adagium: historia philosophiae magistra philosophiae (Swieżawski, 1993a, s. 252).

Łączność filozofii z jej historią, przy uwzględnieniu wielorakich ograniczoności życia ludzkiego, pozwala nie tylko uniknąć powielania przemyśleń z ogromnej 
problematyki filozoficznej, ale ustrzega również przed popełnianymi często błędami (Swieżawski, 1978b, s. 62-65; idem 1978c, s. 61). „Dzięki historii - mówi Swieżawski - nasz warsztat osobisty zwielokrotnia się o całe wieki narastającego wysiłku twórczego tysięcy ludzi parających się tą dziedziną, niezmiernie wprost poszerzając nasze własne «laboratorium» refleksji filozoficznej”) (ibidem).

Historyk filozofii, z drugiej strony, powinien cechować się jasną koncepcją filozofii jako wiedzy, by potrafił rozstrzygnąć, czy badane teksty są filozoficzne i jakiej dyscypliny są wyrazem. Od tego też zależy hierarchia ważności poszczególnych dyscyplin filozoficznych, a w konsekwencji proponowany przez historyka filozofii obraz filozofii i jej dziejów. W tym sensie Swieżawski powie, że historyk filozofii musi być sam filozofem (Swieżawski, 1993a, s. 250-251). Ważna jest jednak świadomość wzajemnej odrębności terenów: historyczno-filozoficznego i stricte filozoficznego. „Na wszystkich etapach badawczych, a zwłaszcza przy ocenianiu faktów historyczno-filozoficznych postrzeganie odrębności tych dwóch płaszczyzn jest sprawą pierwszorzędnej wagi” (ibidem, s. 255). Owo rozgraniczanie wypowiedzi filozoficznych i historyczno-filozoficznych domaga się i jednocześnie gwarantuje realną i twórczą wymianę usług obu tych dziedzin (ibidem, s. 252).

Swieżawski wskazuje również na doniosłą rolę jaką odgrywa historia filozofii dla religii. Stoi on na stanowisku, że każdy człowiek religijny powinien pogłębiać swoją wiedzę o Bogu, a każda teologia potrzebuje wsparcia ze strony filozofii. By lepiej pojąć prawdy Boże, potrzebna jest ogólna mądrość historyczna (m.in. z zakresu kultury, społeczeństwa, dziejów kościoła, teologii itp.), z której nie można wyłączać historii filozofii. Pogłębianie wiedzy o Bogu domaga się korzystania z historii filozofii choćby pośrednio, przez filozofię, dla której przecież jej historia jest niezbywalnym narzędziem (Swieżawski, 1993a, s. 68-69). Jest także sprawą ważną, na jakiej filozofii teologowie opierają swe dociekania oraz do jakiej filozofii odwołują się ludzie wierzący. Nie należy oczywiście nigdy kwestionować pluralizmu w filozofii i teologii, ale na pewno „każdy wybór winien być świadomy i wynikać z nabytej wiedzy historyczno-filozoficznej i metodologicznej. Zgubny tu zawsze jest - podaje Swieżawski za Janem Andrzejem Kłoczowskim - eklektyzm powierzchowny i dyletancki” (Swieżawski, 1995a, s. 41).

Jak w formacji filozoficznej i poniekąd religijnej poruszamy się w sferze mądrości, tak w formacji humanistycznej obcujemy przede wszystkim z wiedzą. Wiedza humanistyczna jest dla Swieżawskiego specyficzna w dwojakim znaczeniu: po pierwsze pozwala nam ona lepiej poznać człowieka i jego dzieła, a po drugie, tego, kto ją uprawia, czyni bardziej człowiekiem. Zatrzymując się przy pierwszym znaczeniu wiedzy humanistycznej, napotykamy i tu szeroką gamę aspektów, w których, w różnych naukach, można ujmować człowieka, jego osobowość i działalność. By, w podejmowanych studiach z zakresu historii kultury, nie fałszować obiektywnego stanu rzeczywistości, koniecznym warunkiem jest ujmowanie zagadnień z zakresu problematyki filozoficznej. Swieżawski twier- 
dzi wręcz, że to właśnie w sferze przedmiotu, którego dotyczą wszelkie nauki historyczne, dzieje filozofii są jednym z istotnych czynników pogłębiających ich humanizację. W drugim znaczeniu studia historyczno-filozoficzne są dogodną sposobnością dla podejmujących te badania, dla ich osobistej formacji humanistycznej. Obcując z tekstami źródłowymi, człowiek winien posiadać i ciągle usprawniać umiejętności filozoficzne, historyczne, filologiczne, a nawet techniczne w zakresie metod badawczych. Przytoczone sprawności, z całą swoją bogatą i wielowarstwową treścią, wywieraja wplyw humanizujący, a to oznacza, że rzetelny historyk filozofii staje się bardziej człowiekiem ${ }^{4}$. Jest rzeczą oczywistą dla Swieżawskiego, że naukowo uprawiana historiografia filozofii nie może być udziałem wszystkich, ale, jak podkreśla, każdy człowiek jest zdolny do uprawiania przednaukowej filozofii. Chodzi tu o kontemplacyjny ${ }^{5}$ i sapiencjalny charakter ujmowania rzeczywistości, który może leżeć u podłoża rozwoju ludzi wszelkich poziomów wykształcenia, znacząco wzbogacając ich formację ogólnohumanistyczną (Swieżawski, 1978b, s. 65-69). Jak pisze Swieżawski:

\begin{abstract}
jest rzeczą bardzo istotną móc się odnaleźć w konkretnej sytuacji czasowo-przestrzennej, zrozumieć wymogi chwili, próbować odczytywać znaki czasu, wnikać w sens ewolucji i przemian, jakie się dokonują, a przy tym nie tylko nie ulec katastrofizmowi i duchowej negacji, nie przerażać się fermentami kryzysu, lecz twórczo i pozytywnie nastawiać się na teraźniejszość i przyszłość. Zdobycie takiej postawy - dla Swieżawskiego - jest niemożliwe dla dzisiejszego człowieka bez pogłębionej znajomości historii (ibidem, s. 69).
\end{abstract}

Historyczna myśl filozoficzna, poza elementem wzbogacającym naszą wiedzę, uczy więc także samodzielnego myślenia. Wdrażanie człowieka w prawdziwy humanizm, opierający się bezmyślności i wszelkiemu spłycaniu, ma znamiona autentycznego rozwoju kultury. Historiografia (także filozoficzna) poprzez pobudzanie do krytycznej refleksji jawi się jako decydujący czynnik, stanowiący o losach tego rozwoju (Swieżawski, 1978a, s. 265).

U podstaw uprawiania każdej historiografii ma leżeć służba prawdzie, rozumianej jako zgodność hipotez historyka z zespołem badanych faktów. Historia nie ma i nie powinna mieć żadnych celów ubocznych poza prawdą, do której dochodzić się będzie jedynie w prawdziwej wolności intelektualnej. Swieżawski nie przyjmuje żadnych kompromisów z fałszem. Stoi na stanowisku, że nawet najgorsza prawda lepiej będzie wzbogacać filozofię, umacniać teologię oraz pogłębiać

${ }^{4}$ Znamienna była rada udzielona Swieżawskiemu przez Tatarkiewicza, który sugerował, by w czasie zajęć seminaryjnych z historii filozofii, poza dawaniem jak największej ilości ujęć syntetyzujących, zostawiać też dużo czasu na dyskusję podczas owych spotkań (por. Swieżawski, 1978a, s. 261).

${ }^{5}$ Kontemplacja jest dla Swieżawskiego kluczowym pojęciem w jego ujęciu filozofii. Jeśli wyodrębni się, za św. Tomaszem z Akwinu, trzy podstawowe działania ludzkie: poznanie (theoria), postępowanie (praxis) i tworzenie (poiesis), to kontemplacja łączy się z pierwszą z wymienionych. „Bo pierwotnie theoria oznaczało nie <teorię> w sensie jakiejś struktury naukowej, tylko kontemplację. Theorien znaczy: oglądać, patrzeć; chodzi tu więc o postawę kontemplacyjną" (Swieżawski, 1995j, s. 154). 
formację humanistyczną niż fałsz pozornie najlepiej służący innym niż prawda celom (Swieżawski, 1978b, s. 70). Przestrzega zatem przed łatwym ześlizgiwaniem się z płaszczyzny filozoficzno-prawdziwościowej na grunt ideologiczny, czy zgodny z jego osobistym światopoglądem.

Historyk filozofii winien śmiało poszukiwać prawdy historyczno-filozoficznej i filozoficznej. Winien pamiętać, że obiektywna prawda jest jedna, ale dróg prowadzących do niej wiele, gdyż z natury ludzkiej wynika aspektowość poznania filozoficznego. Stąd bierze się pluralizm filozofii, który historyk filozofii musi uznać za wyraz normalnie funkcjonującego ludzkiego poznania w zakresie problematyki filozoficznej (Swieżawski, 1993a, s. 254).

Mimo że Swieżawski stoi na stanowisku bezinteresowności filozofii, jak podkreśla Tarnowski, cały jego dorobek historyczno-filozoficzny służy nie tylko wiedzy, ale też kształtowaniu określonej postawy wobec świata, postawy kontemplacyjnej ściśle powiązanej z metafizyką, jako elementem poprzedzającym działanie: widzi on w kontemplacji owoc dziecięcego zadziwienia światem i pokornego zachwytu nad istnieniem. W praktyce znajduje to odzwierciedlenie w otwartości i pokorze wobec rzeczywistości ${ }^{6}$. Opowiedzenie się bowiem za jedną prawdą oraz niezbywalnymi wartościami nie tylko nie wyklucza, ale wręcz zakłada dialog - to tutaj Tarnowski dopatruje się mądrości wytrawnego historyka filozofii. Otwarcie się na innych nie może iść w parze $\mathrm{z}$ chęcią dominacji. Swieżawski domaga się rezygnacji z wszelkiego władztwa, klerykalizmu, nacjonalizmu czy psychologii oblężonej twierdzy. W uprawianej filozofii stara się poszukiwać tego, co wspólne wszystkim ludziom. I nie chodzi tutaj o przekreślanie czy niedostrzeganie różnic, ale o umożliwienie komunikacji. Dopiero taka postawa wydaje się Swieżawskiemu stuszna i godna filozofa (Tarnowski, 1997, s. 95-98).

Swieżawski, reprezentując określony pogląd na świat, spotyka się z uwagą, że jako historyk filozofii narażony jest na bycie nieobiektywnym. Ale przecież nie można żadnemu historykowi filozofii odmówić prawa do własnych poglądów filozoficznych. Owe preferencje nie dewaluują historyczno-filozoficznych badań, a przynajmniej nie powinny. Z całą pewnością tak się dzieje w przypadku Swieżawskiego, który „,Z wielkim obiektywizmem bada swój przedmiot, nie ograniczając się do jednej epoki i do swoich myślicieli" (Turowicz, 1997, s. 100). Sam Swieżawski zresztą zaznacza, że badając każdą filozofię, trzeba chcieć ją zrozumieć, wnikając w jej istotne motywy i w jej glęboki mechanizm (Swieżawski, 1978a, s. 262).

Nawet twórczość filozoficzną, do której żywi niechęć, winien odtworzyć z maksymalną dla niej sympatią. W dobrym wykładzie historii filozofii każdy omawiany pogląd powinien być przedstawiony z tak daleko posuniętą, pełną sympatii bezstronnością, że słuchacz ma odnieść

${ }^{6}$ Obrazem potwierdzającym słuszność wyrażonej opinii przez Tarnowskiego są słowa jej adresata. Swieżawski, pisząc o uczonych historykach filozofii (filozofach) jako o strażnikach źródeł odpowiedzialnych za prawdę, podkreśla: „Filozof jednak i historyk filozofii ponoszą tę odpowiedzialność w sposób szczególny, bo prawda przez nich zdobywana należy do sfery mądrości, a nie tylko wiedzy" (Swieżawski, 1993a, s. 256). 
wrażenie, iż wykładowca jest zwolennikiem tych właśnie filozofii, które aktualnie omawia (Swieżawski, 1993a, s. 265).

U podstaw takich działań miały leżeć ustalenia Wilhelma Diltheya, dla którego przedmiotem humanistyki jest rzeczywistość dziejowo-społeczna, a jej właściwe i autentyczne zrozumienie wyklucza wszelkie fantazje naukowe. Granicznym, ale jedynym ryzykiem takiej metody, w prezentacji niektórych filozofii, może być wrażenie, że prezentującemu je badaczowi są one nie tylko bliskie, ale że jest wręcz ich zwolennikiem. Nie może być natomiast mowy o braku obiektywizmu (Swieżawski, 1978a, s. 262). Przykładem jest Swieżawski, który nigdy nie taił, że uważa metafizykę św. Tomasza za szczytowe osiągnięcie filozofii (Tarnowski, 1997, s. 96). Podobnie zresztą jak Gilson, który „Z równym zapałem prezentował Augustyna, Bonawenturę, Rogera Bacona, Dunsa Szkota czy Tomasza. Miał bowiem wielką umiejętność pokazania tego pluralizmu, co zupełnie nie wykluczało, że jego wybór padł na Tomasza" (Swieżawski, 1995b, Ustawiać..., s. 38). Wskazanie przez historyka filozofii własnej opcji przy okazji prezentowania faktów historycznych $\mathrm{i}$ ich interpretowania było dla Swieżawskiego, jak to ujmują jego komentatorzy, niezbędnym wymogiem uczciwości intelektualnej historyka (Janeczek, 1999, s. 11-12).

W pracy naukowej Swieżawski przypisywał ogromną wagę cnotom moralnym, obok tych intelektualnych. Był świadom, że uczony wskutek szczególnego zbiegu różnych okoliczności, a zwłaszcza z braku pewnych przymiotów ducha, może dojść do stanu, w którym przestaje być człowiekiem i przeobraża się w wyspecjalizowanego owada! Stąd konieczność uzupełniania i wzajemnego wspomagania, w osobie każdego uczonego, sprawności intelektualnych i moralnych. Mówi zatem o postawie maksymalnie realistycznej i uniwersalistycznej, gdzie obie te postawy sq o wiele bardziej owocem cnót intelektualnych "pozawiedzowych»-znajomości pierwszych zasad, mądrości i roztropności - niż samej cnoty wiedzy. Wśród cnót moralnych na plan pierwszy wysuwają się zaś: pracowitość, wytrwałość, sumienność i dokładność - głównie w wykorzystywaniu źródeł. Dobór faktów, który zależy od osobowości historyka, w każdej historiografii musi cechować szczególna odpowiedzialność (Swieżawski, 1993a, s. 257-266).

Przede wszystkim wobec licznych pokoleń naszych poprzedników, którzy nie mogą się bronić ani dyskutować, a których poglądy musimy bezbłędnie odtwarzać, wyjaśniać i przekazywać, ale także wobec współczesności. Rola łącznika między przeszłością i współczesnością sprawia, że przeszłość nie jest tylko zabytkiem, ale źródłem żywych inspiracji, dla czasów i środowiska, w których żyje i działa historyk (ibidem).

Ważne też jest, według Swieżawskiego, aby historyk filozofii cechował się dystansem do własnych dzieł. Konieczna jest świadomość, że propozycje wyjaśnienia badanych tekstów filozoficznych zostaną kiedyś zastąpione przez lepsze. Należy wręcz doszukiwać się satysfakcji z faktu, że jego uczniowie (następcy) w sposób bardziej wnikliwy przedstawią wyjaśnienia harmonizujące $\mathrm{z}$ całością badanej rzeczywistości. 
Niekiedy - mówi Swieżawski - szczytowym przejawem prawdziwego uczonego jest nagłe uświadomienie sobie znikomości własnych ogromnych trudów intelektualnych - jak u św. Tomasza z Akwinu, który u kresu swej ziemskiej wędrówki i w oczekiwaniu pełni rzeczywistości porównał całe dzieło swego życia do garści słomy (Swieżawski, 1993a, s. 255-256).

\section{Rola Ewangelii}

Swieżawski sukces kościoła, do którego przynależał, widział w czystości świadectwa dawanego Ewangelii. Winno ono cechować się coraz większą intensywnością przeżywanej wiary i być antytezą religii pojmowanej jako władztwo nad milionami dusz. Rozwój ewangelicznej wiary nie domaga się zatem, jakby mogło się wydawać, warunków dominacji chrystianizmu - istnieje wtedy ryzyko jego pozorności. Zgodnie z wytycznymi Soboru Watykańskiego II, autentyczne chrześcijaństwo ma charakteryzować: wspólnotowość, służebność i otwartość, których to urzeczywistnienie może być współcześnie gwarantem prawdziwego, jak to określa Swieżawski, uchrześcijanienia. W tym duchu dokonana reforma kościoła, zdaniem Swieżawskiego, musi wyjść od reformy mentalności; wyzucia sie ze wszystkich ciasnot feudalno-klerykalno-konstantyńsko-<tomistycznych $>$ (Swieżawski, 1995b, s. 12-14). Dawanie świadectwa Ewangelii, będące zaprzeczeniem tworzenia jedynie struktur i systemów, jest tożsame ze świadectwem dawanym prawdzie. Swieżawski powie: „Chrześcijanin jest powołany do tego, aby urzeczywistniać zadanie sformułowane przez Chrystusa w rozmowie z Piłatem: Ja się na to narodzitem i na to przyszedlem na świat, aby dać świadectwo prawdzie (J 18, 37)" (Swieżawski, 2004, s. 14). Mając na uwadze wcześniej prezentowane poglądy Swieżawskiego, koniecznym wydaje się dopowiedzenie tutaj, że w żywym i skutecznym świadczeniu Ewangelii, nieodzowne jest przyjęcie prawdy historycznej jak i zrozumienie znaków czasu.

Historyczne spaczenia i błędy religii chrześcijańskiej, które często znaczą ją po dzień dzisiejszy, w najmniejszym stopniu nie są w stanie zachwiać przekonaniem Swieżawskiego o wyjątkowości chrześcijaństwa zakotwiczonego w Ewangelii. Nie łączy to się z jakimkolwiek potępianiem religii niechrześcijańskich, które same w sobie posiadają również określone cząstki prawdy - prawdy jednak nieobjawionej (Kalinowski, Swieżawski, 1995, s. 26).

Swieżawski w chrześcijaństwie odsłania przede wszystkim jego kontemplacyjne oblicze. Przeciwstawia się tym samym m.in. XV-wiecznym humanistom, którzy kontemplacyjnemu stylowi życia przeciwstawiali chrześcijaństwo z jego praktyczną miłością bliźniego. Swieżawski, nie absolutyzując kontemplacji, głosi jednak jej logiczną pierwotność wobec działania, podobnie jak J. Maritain, którego opinię przytacza:

Chrześcijaństwo [...] przekształciło pojęcie kontemplacji, która nie zamyka się odtąd w intelekcie, ale jedynie w miłości kontemplowanego Boga; przywróciło działaniu jego ludzki sens 
służby bliźniemu. Tak więc działanie pochodzi z nadmiaru kontemplacji: oto kontemplacja daleka od usuwania działania lub od przeciwstawiania się mu, ożywia je (Kalinowski, Swieżawski, 1995, s. 26-27).

Swieżawski wskazuje na fakt ścisłej współzależności prawdy i dobra. Mówi o sferze poznania i sferze moralności jako o jednej rzeczywistości cechującej ludzką aktywność. Zagadnienie prawdy nierozerwalnie złączone jest $\mathrm{z}$ zagadnieniem dobra - apeluje tym samym o przywrócenie równowagi między sferami logosu i ethosu. Pytanie o moralne dobro łączy z pytaniem o sens otaczającej nas rzeczywistości i o nasze w niej miejsce. Ogromną rolę w tym działaniu przyznaje realistycznej filozofii, która próbuje dotrzeć do ostatecznych racji istnienia bytów (metafizyka) i jednocześnie próbuje zgłębić tajemnicę człowieka (antropologia filozoficzna). W sposób bardziej pełny sprawy te jawią się jednak dopiero na płaszczyźnie wiary. Odkrywana wtedy, choćby tylko częściowo, absolutna prawda o świecie i o człowieku przynosi kodeks ogólnych wytycznych moralnych. Odnalezienie zatem obiektywnej prawdy jest odnalezieniem obiektywnego prawa naturalnego, które winno leżeć u podstaw absolutnej moralności i właściwej skali wartości. I jak Dekalog jawi się w poszczególnych sumieniach jako obiektywne prawo naturalne, tak specyficznym pozostaje typowo chrześcijańskie, ewangeliczne prawo miłości i Ośmiu Błogosławieństw (Mt 5, 3-12), które budowane jest na prawie naturalnym, ale je jednocześnie udoskonala poprzez wzywanie do świętości (Swieżawski, 1995c, s. 11-15). Swieżawski, przeciwstawiając się prymatowi ethosu nad logosem, wykazuje, że „relatywizm prawdy prowadzi nieuchronnie do relatywizmu moralnego. Kapitulacja zaś ludzkiego intelektu objawiająca się zwątpieniem w istnienie absolutnej prawdy i możliwości dotarcia do niej, jest ciosem śmiertelnym zadanym naturze ludzkiej i jej godności" (ibidem, s. 15).

Swieżawski ubolewa, że największe prawdy i wartości Dobrej Nowiny często trafiają $\mathrm{w}$ pustkę. Winą za to obarcza zaniedbania $\mathrm{z}$ poziomu, jak to określa, niezbędnej podbudowy, która jest konieczna do przyjęcia Ewangelii. Owo praeparatio evangelica, zakładając istotną różnicę porządków przyrodzonego i nadprzyrodzonego, dokonuje się w sferze przyrodzonej, stanowiąc tym samym swoiste praeambula fidei. Porządek naturalny obejmuje i sferę poznania (mądrość filozoficzna), i sferę działania (akonfesyjna moralność). Z jednej strony więc człowiek może w sposób naturalny poznać istnienie Boga oraz niektóre jego przymioty, z drugiej, w swoim sumieniu może odczytać główne zasady prawa naturalnego - i wszystko to bez pomocy Objawienia. Metafizyka zatem i prawo naturalne stanowią kanwę tej różnorodnej budowy, jaką jest w całym swoim bogactwie kultura. I posiadaja jeszcze jeden istotny atut: w pełni realistyczna filozofia i etyka przyrodzona są z istoty swojej otwarte, także na przyjęcie nadprzyrodzoności, na perspektywy transcendentalne i religijne, a więc i na posłanie ewangeliczne (Swieżawski, 1995d, s. 26-27). Filozofia może mieć swoje przedłużenie w wierze konkretnego człowieka. Ale również w filozofii wiele impulsów pochodzi ze źródła religijnego. 
W ogóle myślenie o Bogu - mówi Swieżawski - choć jawi się dopiero u człowieka religijnego, jest zasadniczo problematyką filozoficzną, ale pojawia się tam, gdzie istnieją niezbędne impulsy. Gdy czyta się Summę teologii św. Tomasza, to widać, ile jest tam elementu czysto filozoficznego, ile teologicznego czy biblijnego. One w pewnych momentach schodzą się i to jest zdumiewająca prawda, że łączy się refleksja filozoficzna z Objawieniem (Swieżawski, 1995b, s. 37).

Chrześcijaństwo jednak, zaznacza Swieżawski, nie domaga się ze swojej natury nowej filozofii - filozofii chrześcijańskiej. Postrzegając filozofię św. Tomasza z Akwinu jako kolejny krok w linii Platon - Arystoteles - Awicenna - Majmonides, jest skłonny uniezależnić ją od chrześcijaństwa. Zwraca jedynie uwagę na znaczenie metafizyki i impulsy płynące z Biblii - a nasuwające całe bogactwo treści filozoficznych, ze sławnym JESTEM, KTÓRY JESTEM (Wj 3, 14), lub Chrystusowym: Zanim Abraham stat się, JA JESTEM (J 8, 58) - które nie tylko odgrywały rolę katalizatora przemyśleń filozoficznych, jak powie Swieżawski, ale pozwoliły posunąć naprzód całą problematykę filozoficzną (Swieżawski, 1993b, s. 318 oraz idem, 1995b, s. 36-37). W nieco innym aspekcie, ale zgodnym z duchem filozofowania św. Tomasza, Swieżawski powie, że szukanie kamienia filozoficznego to jest ostatecznie szukanie Boga (Swieżawski, 1995b, s. 40).

Swieżawski z aprobatą odnosi się do wypracowanego przez Sobór Watykański II programu nowej ewangelizacji, w myśl którego, paradoksalnie, dostosowanie chrześcijaństwa do współczesnych potrzeb miałoby polegać przede wszystkim na powrocie do źródeł, na odkryciu na nowo Ewangelii, wierność której przynosiłaby ze sobą świętość życia. Nową ewangelizację ma cechować uniwersalizm, w przeciwieństwie do ewangelizacji średniowiecznej, która niewatpliwie dokonata wielkich dziel, ale właściwie nie wyszła poza klasztory i środowiska elitarne, nie sięgnęła do społeczeństwa (Swieżawski, 1995e, s. 208). Pozostawanie, deklarujących się jako chrześcijanie, ludzi w półmagicznym pogaństwie jest również w przekonaniu Swieżawskiego typowe, choć w nieco innym znaczeniu, dla czasów współczesnych - chrześcijanie nie żyją bowiem pełnią życia chrześcijańskiego. Wynika stąd potrzeba swoistego zindywidualizowania chrześcijaństwa, co znalazłoby wyraz w autentycznych osobistych wyborach oraz w coraz bardziej świadomym przeżywaniu tego, co stanowi istotę przyjętej wiary. Nie może się to jednak dokonać bez wspomnianej podbudowy intelektualnej, bez pogłębienia wiedzy religijnej u wszystkich wierzących - oczywiście w miarę osobistych możliwości intelektualnych (Swieżawski, 1995f, s. 68-69; 1995g, s. 81-85).

Nowej ewangelizacji sprzeciwia się również - w mniemaniu Swieżawskiego, po dzień dzisiejszy odbijający się echem - duch walki, który przenika chrześcijan w konsekwencji wychowania w duchu kontrreformacji. W polskiej rzeczywistości protoplastami takiego nastawienia pozostają Piotr Skarga i Henryk Sienkiewicz, których wizjom Swieżawski przeciwstawia ideały jagiellońskie. Ówczesne chrześcijaństwo nie tylko nie było nacechowane jeszcze duchowościa walk religijnych (Swieżawski, 1995g, s. 86), ale wręcz życie zbiorowe cechowały takie 
postawy jak ekumenizm, tolerancja, pacyfizm, demokracja. Życie to mogli kształtować ludzie o głęboko uzasadnionych przekonaniach humanistycznych, m.in. tego pokroju co Paweł Włodkowic, który podkreślał, że „prawo ewangeliczne jest prawem miłości, zgody i pokoju, nie zaś strachu, nieporozumienia lub wojen" (za: Swieżawski, 1995h, s. 176). Swieżawski zatem, odwołując się do głęboko humanistycznych, chrześcijańskich tendencji Jagiellonów w tworzeniu państwowości, postuluje, by ludzi o innych przekonaniach nie traktować jak wrogów. Dotyczy to nie tylko chrześcijan, ale i wszystkich wierzących i niewierzących. Ze wszystkimi ludźmi mamy coś wspólnego, bez konieczności ustępowania z własnych poglądów (Swieżawski, 1995f, s. 68).

Fundamentalne jest zatem osobiste przekonanie co do wyznawanej wiary, umiejętność uzasadniania wyborów religijnych, ale nie mniej doniosłe znaczenie odgrywa również relacja chrześcijan w stosunku do osób o innej religijności, poszukujących lub niewierzących. Swieżawski mówi wręcz o wzajemności przysług w owych relacjach, gdzie condicio sine qua non pozostaje chrześcijańskie świadectwo życia ${ }^{7}$ dawane Ewangelii.

Niewierzący i szukający prawdy - zaznacza - powinni być bodźcem naszych ustawicznych nawróceń, a tylko autentyczność naszej metanoi może się przyczynić do zbliżenia się do wiary tych, którzy są od niej daleko. Nasze własne świadectwo, że traktujemy poważnie wiarę i Ewangelię - i że się ciągle nawracamy, aby wobec posłania ewangelicznego być coraz wierniejszymi - jest najwłaściwszą i powszechnie stosowaną metodą ewangelizacji (Swieżawski, 1978d, s. 179).

Autentyczne chrześcijańskie świadectwo, wyrażające się w żywej wierze i prawdziwej miłości, Swieżawski postrzega we współczesnych czasach jako, jak to określa, pierwsza potrzebę chwili obecnej (Swieżawski, 1978e, s. 109) ${ }^{8}$.

W ewangelizacji „niezbędna jest mnogość dróg i doświadczeń, a bardzo niebezpieczna uniformistyczna jedność linii” (Swieżawski, 1978f, s. 91). Dlatego Swieżawski z upodobaniem przywołuje ewangeliczną przypowieść o zaczynie, wedle której Ewangelia miałaby promieniować i przenikać wszystkie struktury życia społecznego, nie zaś być odgórną dyspozycją, czy tym bardziej nieznoszą-

\footnotetext{
${ }^{7}$ Wartość świadectwa chrześcijańskiego tym bardziej nabiera znaczenia, jeśli weźmie się pod uwagę obserwowaną dewaluację słowa. Swieżawski piętnuje dysonans, jaki coraz bardziej dzieli piękne słowa i czyny, które nie urzeczywistniają owych pięknych zdań $i$ wielkich słów. Pisze on: „człowiek dzisiejszy bywa zbyt często zdradzany przez różne kazania pełne pięknych zdań i wielkich słów. Stracił więc do nich zaufanie. Człowiek ten ma więcej zaufania do potęgi i wymowy milczenia i do świadectwa czynów niż do słów, które mu już wiele nie mówią" (Swieżawski, 1978e, s. 107).

${ }^{8}$ Przy okazji wskazywania na cechy autentycznego chrześcijaństwa, Swieżawski wskazuje na niezbywalną wartość modlitwy, która nastawia życie ludzkie ku Bogu; która wyzwala z błędnego koła egocentryzmu i staje się szkoła kontemplacji. Poza tym modlitwa, wbrew błędnym przekonaniom, jak dowodzi Swieżawski, prawdziwie zakorzenia nas w rzeczywistości poprzez więzy z Bogiem, źródłem całej rzeczywistości. Nie gdzie indziej niż w Bogu, najwyższej rzeczywistości, odnajdujemy ostateczna rację chrześcijaństwa i realizmu - powie (Swieżawski, 1978e, s. 109-110).
} 
cym sprzeciwu nakazem. W takim duchu kościół przetransformował swoją rolę na Soborze Watykańskim II, co było jednoznaczne z powrotem do ewangelicznej autentyczności. „Zamiast tworzyć kulturę katolicką, konfesyjną i sakralną, obok wielu podobnych (ale niekatolickich) kultur, usiłuje teraz przenikać wszystkie istniejące kultury zakwasem Ewangelii, głęboko przeobrażając charakter wszystkich tych poszczególnych kultur" (Swieżawski, 1993c, s. 115). Świadomość tego faktu, jak również gruntowna znajomość historii, stała się dla Swieżawskiego przesłanką sformułowania śmiałej (zważywszy na dwa tysiące lat chrześcijaństwa, liczne sobory i próby reformy kościoła) konstatacji: „Nie jest, jak sądzę, przesadą twierdzić, że ostatni Sobór - po raz pierwszy w historii - rozpoczął prawdziwą odnowę ewangeliczną w Kościele" (ibidem, s. 120).

Ogromne znaczenie przypisuje Swieżawski również zadaniu kształtowania sumienia, które z kolei jest $\mathrm{w}$ stanie przekształcać etykę chrześcijańską, często klanową - jak ją określa - w etykę ewangeliczną. Wysoko zaś ceniona godność sumienia nie pozwoli chrześcijaninowi wyobcować się z wszelakich napięć dzisiejszego świata, musi on tkwić w nim catkowicie i reagować zgodnie z Ewangelia (Swieżawski, 1978d, s. 138). Niekwestionowaną rolę w formowaniu sumienia i kształtowaniu osobowości odgrywa wychowanie, i to już od najwcześniejszych lat. Nie mogą dziwić zatem słowa Ewangelii: „Jeśli nie staniecie się jako dzieci, nie wejdziecie do królestwa niebieskiego" (Mt 18, 3). Swieżawski, przytaczając ten ewangeliczny cytat odwołujący się do najpiękniejszych przymiotów dziecięctwa, wskazuje na ich niezbywalną wartość dla życia nadprzyrodzonego, które domaga się najpetniejszego uznania całej dziedziny przyrodzonej i jej właściwych praw (Swieżawski, 1978e, s. 112-117).

Nie może dziwić, że Swieżawski, reprezentując taką, a nie inną ewangeliczną postawę życiową, sympatyzował m.in. z takimi postaciami jak Charles de Foucauld ${ }^{9}$, Matka Teresa z Kalkuty, ks. Władysław Korniłowicz ${ }^{10}$, ks. Jan Zieja ${ }^{11}$ czy Jacques Maritain, który ostatecznie wstąpił w Tuluzie do wspólnoty

${ }^{9}$ Charles de Foucauld (1858-1916) - francuski arystokrata, konwertyta. Poszedł po krańce świata, aby swoim życiem głosić Ewangelię. Chciał mieć uczniów, zakładać wspólnoty. Ciężka reguła, którą stworzył, ostatecznie uniemożliwiła za życia ziszczenie zamiarów. Zginął podstępnie zabity. Stał się inspiratorem nowej duchowości w Kościele oraz wielu zgromadzeń zakonnych (Mali Bracia i Małe Siostry Jezusa), które powstały dopiero po jego śmierci. Dewizą ich życia jest: być Arabem wśród Arabów, robotnikiem wśród robotników, nomada wśród nomadów, a przede wszystkim Człowiekiem pomiędzy Ludźmi. Zakonnicy nie używają stroju zakonnego, tworzą małe wspólnoty (3-5 osobowe); kontemplując i pracując w środowiskach świeckich, prowadzą chrześcijańskie życie w braterstwie i ubóstwie. Od 1977 r. obecni w Polsce.

${ }^{10}$ Władysław Korniłowicz (1884-1946) - w latach I wojny światowej wraz z A. Małachowskim organizował polskie harcerstwo. Profesor Katolickiego Uniwersytetu Lubelskiego. Od 1920 r. sprawował opiekę nad zakładem dla ociemniałych w podwarszawskich Laskach.

${ }^{11}$ Jan Zieja (1897-1991) - duszpasterz i działacz społeczny. Uczestnik Powstania Warszawskiego. Związany z ZMW RP i środowiskiem podwarszawskich Lasek. Zorganizował i prowadził Dom Samotnej Matki w Słupsku. Od 1976 r. współtwórca i członek KOR, rzecznik ekumenizmu oraz dialogu z judaizmem (jeszcze przed Soborem Watykańskim II). 
Małych Braci Ch. de Foucauld. Wszyscy oni ukształtowani w duchu autentycznego, ewangelicznego chrześcijaństwa, cechowali się bezwzględną konsekwencją w urzeczywistnianiu tego, w co wierzyli, poprzez służbę i oddanie się drugiemu człowiekowi. Swieżawski, przy wielu okazjach odwołując się do nich, z całą mocą podkreśla: ten styl życia duchowego wydaje się duchowościa nadchodzacej epoki (Swieżawski, 1995i, s. 224).

Swieżawski wskazuje na Ewangelię jako na zasadniczy czynnik kształtujący kulturę. U podstaw takiego ujęcia leżą dwa podstawowe aspekty: problematyka mądrości i zagadnienie stosunków międzyludzkich. Obserwacja świata przynosi ze sobą często obraz niesprawiedliwości, nieludzkiego współżycia. Mówi stąd o deficycie mądrości: wielkie i mniejsze konflikty wybuchaja najczęściej dlatego, ż wielcy nie należa do grona ludzi madrych. W tych to okolicznościach wskazuje na ogromną rolę do odegrania, którą mają chrześcijanie, pod warunkiem jednak, że ich chrystianizm poważnie traktować będzie Ewangelię (Swieżawski, 1978g, s. 80-81). „Chrześcijanie, czerpiąc swe natchnienie z Ewangelii, powinni być zawsze i wszędzie tym czynnikiem, który wbrew antyhumanistycznym, a przez to $i$ antykulturalnym tendencjom wnosi w doczesne dziedziny życia prawdziwe wartości ludzkie i rzeczywistą uniwersalizację umysłów" (ibidem).

Uznanie różnorodności i wielości tendencji w ramach samego chrześcijaństwa, wieloaspektowości poznania: w porządku przyrodzonym wielość filozofii, a w porządku nadprzyrodzonym wielość teologii, w przekonaniu Swieżawskiego, w niczym nie uwłacza jedności treści zawartej w Ewangelii (Swieżawski, 1978f, s. 88). Kościół nie daje gotowych, szczegółowych rozwiązań. Każdy osobiście musi więc poszukiwać własnych rozstrzygnięć teoretycznych i praktycznych. Tym samym Swieżawski usprawiedliwia ewentualne ludzkie błądzenie (będące efektem ubocznym poszukiwań). Jest ono bowiem wpisane w ryzyko autentycznego myślenia, które, nawet jeśli naraża się na błędy, jest bardziej wartościowe niż bierny stosunek do rzeczywistości i rezygnacja z własnego zdania (Swieżawski, 1978d, s. 135). Na charakteryzującą Swieżawskiego tolerancję dla odmiennego myślenia czy wręcz dla błędów, wskazuje Tarnowski, który podkreśla, że

tolerancja ta znajduje się na antypodach postmodernistycznej nijakości: idzie w parze z wyjątkową siłą przekonania, gdzie leży prawda. Jest tak dlatego, że w przeciwieństwie do postmodernistów Swieżawski nie tylko głęboko wierzy w Ewangelię, ale także w ludzki rozum, który nie może być jedynie źródłem złudzeń czy transcendentalnego pozoru, jeżeli człowiek został stworzony wraz ze swoim rozumem przez Boga (Tarnowski, 1997, s. 96).

Historia filozofii i (historycznie przecież osadzona) Ewangelia to dwa zasadnicze filary twórczości i w ogóle życia Swieżawskiego.

Systematyczne zgłębianie przeszłości nie przeszkodziło jednak Profesorowi pozostawać dzieckiem swoich czasów, zatroskanym o chwilę obecną i o przyszłość. Z bogactwa przeszłości czerpał wzorce uniwersalne i ponadczasowe, których odrzucenie pociągałoby za sobą okre- 
ślone niebezpieczeństwa. Mówił o reagowaniu zgodnym z duchem Ewangelii. Wskazywał m.in. na Tomaszowy pluralizm i odwagę myślenia. Przywoływał ideały społeczno-polityczne, szczególnie te z czasów Polski Jagiellonów: demokrację, humanizację życia, tolerancję religijną i narodową, i wreszcie pokój. Brzydził się nacjonalizmem, ksenofobią, a szczególnie wojną. Powtarzał: nie ma wojny sprawiedliwej, każda wojna jest barbarzyństwem (Kamiński, 2004, s. 427).

Uczestnicząc w uroczystości pogrzebowej Stefana Swieżawskiego, odczuwało się smutek płynący z faktu żegnania człowieka wyjątkowego. Jego wyjątkowość wyrażała się w powszechnym odczuciu dobrze przeżytego życia. W czasie ceremonii pożegnania najczęściej bodajże padało słowo MISTRZ. Józef Życiński określił Swieżawskiego mistrzem uczacym polifonii bytu i duchowej niezależności, który odpowiedzialność intelektualna tączyt $z$ wrażliwościa etyczna $i$ estetycz$n a$. Jan Paweł II, w liście odczytywanym w czasie pogrzebu, wspominał o swoich bliskich kontaktach z prof. Swieżawskim, o jego zasługach; podkreślał: przez całe życie poszukiwat mądrości w historii ludzkiej myśli.

Biografie, w kontekście edukacji, powinny przestrzegać lub uczyć - choć niewiele jest przykładów jednoznacznych. Biografia, która stała się udziałem Stefana Swieżawskiego jest łatwa do zakwalifikowania... Odszedł mistrz życia, który także w śmierci widział nadzieję. Swieżawski we względnym zdrowiu, w pełnej sprawności intelektualnej przeżył 97 lat. Niecały rok wcześniej zmarła jego żona Maria ze Stadnickich (razem przeżyli ponad 70 lat). Uroczystość pogrzebowa odbyła się w podwarszawskich Laskach. Na sosnowej trumnie z ciałem zmarłego stała fotografia przestawiająca uśmiechniętego profesora...

\section{Literatura}

Bonowicz W., 2004, Wstęp, [w:] S. Swieżawski, Alfabet duchowy, Znak, Kraków.

Janeczek S., 1999, Filozofia na KUL-u. Nurty, osoby, idee, Redakcja Wydawnictw KUL, Lublin.

Jaworski M., 1975, Władystaw Tatarkiewicz, Warszawa.

Kalinowski J., Swieżawski S., 1995, Filozofia w dobie Soboru, Biblioteka WIĘZI, Warszawa.

Kamiński K., 2002, Kondycja współczesnego człowieka. Wywiad z S. Swieżawskim, „Gość Niedzielny", 27 stycznia, nr 4, s. 16.

Kamiński K., 2004, Profesora Stefana Swieżawskiego umiłowanie mądrości, „Łódzkie Studia Teologiczne", nr 13, s. 427-429.

Kamiński K., 2007, Humanizm chrześcijański Stefana Swieżawskiego, Oficyna wydawnicza LEKSEM (www.leksem.pl), Łask.

Krąpiec M. A., 1997, <Siatka metafizyczna > w studium historii filozofii, „Kwartalnik filozoficzny”, nr XXV, zesz. 1.

Swieżawski S., 1978a, Władysław Tatarkiewicz jako historyk filozofii, [w:] idem, Człowiek i tajemnica, Znak, Kraków.

Swieżawski S., 1978b, Rola historii filozofii w formacji umysłowej, [w:] idem, Człowiek i tajemnica, Znak, Kraków.

Swieżawski S., 1978c, Zbieżność metafizyki realistycznej i historiografii, [w:] idem, Człowiek i tajemnica, Znak, Kraków. 
Swieżawski S., 1978d, Chrześcijanin w środowisku naukowym, [w:] idem, Człowiek i tajemnica, Znak, Kraków.

Swieżawski S., 1978e, Kultura jako podłoże życia nadprzyrodzonego, [w:] idem, Człowiek i tajemnica, Znak, Kraków.

Swieżawski S., 1978f, Jedność uniformizmu, czy zjednoczenie w różnorodności, [w:] idem, Człowiek i tajemnica, Znak, Kraków.

Swieżawski S., 1978g, Czy Ewangelia jest kulturotwórcza, [w:] idem, Człowiek i tajemnica, Znak, Kraków.

Swieżawski S., 1989, Wielki przetom (1907-1945), Redakcja Wydawnictw KUL, Lublin.

Swieżawski S., 1991, W nowej rzeczywistości (1945-1965), Redakcja Wydawnictw KUL, Lublin.

Swieżawski S., 1993a, Etos historyka filozofii, [w:] idem, Istnienie i tajemnica, Redakcja Wydawnictw KUL, Lublin.

Swieżawski S., 1993b, Liturgia jako jedno ze źródet inspiracji filozoficznej, [w:] idem, Istnienie i tajemnica, Redakcja Wydawnictw KUL, Lublin.

Swieżawski S., 1993c, Vaticanum II a problemy kultury wspótczesnej, [w:] idem, Istnienie i tajemnica, Redakcja Wydawnictw KUL, Lublin.

Swieżawski S., 1993d, Owoce życia (1966-1988), Redakcja Wydawnictw KUL, Lublin.

Swieżawski S, 1995a, O roli, jaka chrześcijaństwo wyznacza filozofii, [w:] idem, Dobro i tajemnica, Biblioteka WIĘZI, Warszawa.

Swieżawski S., 1995b, Ustawiać żagle, z prof. S. Swieżawskim rozmawia A. Karoń-Ostrowska i Z. Nosowski, [w:] idem, Święty Tomasz na nowo odczytany, W DRODZE, Poznań.

Swieżawski S., 1995c, Pytanie o absolutne dobro, [w:] idem, Dobro i tajemnica, Biblioteka WIĘZI, Warszawa.

Swieżawski S., 1995d, Jak uniknąć przekleństwa <wieży Babel>, [w:] idem, Dobro i tajemnica, Biblioteka WIĘZI, Warszawa.

Swieżawski S., 1995e, Ku pokrzepieniu serc, [w:] idem, Dobro i tajemnica, Biblioteka WIĘZI, Warszawa.

Swieżawski S., 1995f, Wszyscy jesteśmy grzesznikami, [w:] idem, Dobro i tajemnica, Biblioteka WIĘZI, Warszawa.

Swieżawski S., 1995g, Kościót wspólnotowy, stużebny, otwarty, [w:] idem, Dobro i tajemnica, Biblioteka WIĘZI, Warszawa.

Swieżawski S., 1995h, Etos polityczny Polski Jagiellonów, [w:] idem, Dobro i tajemnica, Biblioteka WIĘZI, Warszawa.

Swieżawski S., 1995i, Znak czasu. Wokół postaci ks. Jana Zieji, [w:] idem, Dobro i tajemnica, Biblioteka WIĘZI, Warszawa.

Swieżawski S., 1995j, Święty Tomasz na nowo odczytany, W DRODZE, Poznań.

Swieżawski S., 1997, Wolność w filozofii, z prof. S. Swieżawskim rozmawia J. Weksler-Waszkinel, „Kwartalnik Filozoficzny”, nr XXV, zesz. 1.

Swieżawski S., 2004, Alfabet duchowy, Znak, Kraków.

Tarnowski K., 1997, Mistrz, „Kwartalnik Filozoficzny”, nr XXV, zesz. 1.

Turowicz J., 1997, Intelektualista katolicki, „Kwartalnik Filozoficzny”, nr XXV, zesz. 1. 